\title{
DO PAYROLL TAX BREAKS STIMULATE FORMALITY? EVIDENCE FROM COLOMBIA'S REFORM
}

\author{
Adriana Kugler \\ Maurice Kugler \\ Luis Omar Herrera Prada \\ Working Paper 23308 \\ http://www.nber.org/papers/w23308 \\ NATIONAL BUREAU OF ECONOMIC RESEARCH \\ 1050 Massachusetts Avenue \\ Cambridge, MA 02138 \\ April 2017
}

We are grateful to Mariano Bosch, Matías Busso, Santiago Levy, Carmen Pages, as well as participants of the workshop organized by the IADB for this project and at the Latin American and Caribbean Economic Association Conference for their helpful comments. This project was funded by Labor Markets and Social Security Unit of the Inter-American Development Bank. The views expressed herein are those of the authors and do not necessarily reflect the views of the National Bureau of Economic Research.

NBER working papers are circulated for discussion and comment purposes. They have not been peer-reviewed or been subject to the review by the NBER Board of Directors that accompanies official NBER publications.

(C) 2017 by Adriana Kugler, Maurice Kugler, and Luis Omar Herrera Prada. All rights reserved. Short sections of text, not to exceed two paragraphs, may be quoted without explicit permission provided that full credit, including $\odot$ notice, is given to the source. 
Do Payroll Tax Breaks Stimulate Formality? Evidence from Colombia's Reform

Adriana Kugler, Maurice Kugler, and Luis Omar Herrera Prada

NBER Working Paper No. 23308

April 2017

JEL No. H2,J2,J24,J31

\begin{abstract}
Alternative work arrangements have grown rapidly around the world. In Latin America, these alternative work arrangements have long been part of the labor market and have continued to grow. The informal sector grew rapidly in Latin America over the past few decades comprising up to half of the working population in many countries. Some attribute the growth in alternative work arrangements and informality to regulations and taxes, while others argue that it is precisely the lack of enforcement of regulations that allows unprotected employment arrangements to flourish. We examine whether reducing taxes associated with employment stimulates formal sector employment. We exploit the fact that the Tax Reform introduced in Colombia in 2012 affected only certain types of workers and not others. In particular, workers earning less than 10 minimum wages (MW) and self-employed workers with more than 2 employees experienced a reduction of payroll taxes of $13.5 \%$ between 2013 and 2014. We use the Colombian Household Surveys, Social Security records and the Monthly Manufacturing Sample to conduct differencein-difference analyses of the reform. We find evidence of increased formal employment for the affected groups after the reform using all three datasets. We find that the probability of formal employment and the likelihood of transitioning into registered employment increased for the affected groups after the reform. We also find that the level and share of permanent employment relative to temp employment grew after the reform for those earnings less than $10 \mathrm{MW}$. The results are greatest for those in smaller firms and those earnings close to the MW.
\end{abstract}

Adriana Kugler

Georgetown University

McCourt School of Public Policy

37th and O Streets NW, Suite 311

Washington, DC 20057

and NBER

ak659@georgetown.edu

Maurice Kugler

IMPAQ International LLC

1101 Vermont Avenue NW

Suite 1100

Washington, DC 20005

mkugler@impaqint.com
Luis Omar Herrera Prada

The World Bank

1818 H Street, NW

Washington, DC 20433

luis.o.herrera@me.com 


\section{Introduction}

Latin America and other developing regions depend on payroll taxes to finance pensions, disability and maternity benefits, and worker's compensation that compensates those with workplace injuries. In the case of Colombia, payroll taxes are also used to finance the National Vocational Training Service (Servicio Nacional de Aprendizaje, SENA, in Spanish) and the Colombian Institute for Family Welfare (Instituto Colombiano de Bienestar Familiar, ICBF, in Spanish). Until very recently, mandatory contributions in Colombia were close to the European median, where the payroll tax rate was about 40 percent (Gill et al., 2005). However, payroll contributions are much higher compared to countries with relatively less regulated labor markets, such as the United Kingdom and the United States, where contributions have fluctuated between 15 and 20 percent of total compensation (OECD, 2015).

In Latin America and continental Europe, high payroll taxes increase the labor costs that companies have to pay, thus discouraging companies from hiring workers. Nonetheless, from a theoretical perspective, the impact of payroll taxes on the labor market is ambiguous. On one hand, when workers value the benefits paid for with payroll taxes as much as the amount they contribute, increases in payroll taxes are fully passed through from companies to employees in the form of lower salaries, with a neutral effect on unemployment. Consequently, in this case, companies do not experience increases in their overall labor costs. On the other hand, if wages are not fully flexible or if payroll taxes fund services that do not directly benefit all employees (such as SENA or ICBF), then wages would not absorb the total payroll taxes as lower wages and there would be an increase in labor costs and a reduction in employment.

Empirical studies from various countries show mixed evidence regarding the impact of

payroll taxes on employment and wages. For instance, Gruber and Krueger (1991) and Gruber 
(1994) find neutral effects on employment in the United States (i.e., full pass-through of taxes onto wages). Gordon (1972) also finds full pass-through taxes onto wages and no impact on employment in the United States. Nevertheless, Vroman (1974) and Harmermesh (1979) find that there is partial pass-through with non-neutral effects on wages and employment. Kaestner (1996) finds that there is no pass-through from payroll taxes onto wages for young workers in the United States.

In most Latin American countries, minimum wages are relatively high and constitute a binding restriction on formal sector employment (see, for example, Maloney et al., 2004). As a result, in this context, it is not feasible to pass-through higher payroll taxes to employees as lower wages, so it is more likely that increases in payroll taxes reduce formal employment. Gruber (1997) finds that a reduction in payroll taxes is completely passed-through to employees in the form of higher wages, without an impact on employment, in Chile. By contrast, Kugler and Kugler (2009) find that a 10 percent increase in payroll taxes reduces manufacturing employment by five percent among the least skilled workers. In this context, the increase in payroll taxes was not transferred to employees through lower wages. This finding is consistent with evidence provided by Maloney et al. (2004) that the minimum wage was binding in Colombia at the time.

In the current study, we explore the effects of the recent drop in the payroll tax rate associated with the Tax Reform, Law 1607, implemented at the end of 2012. The goal of this reform was to increase employment and, in particular, formal employment. As a result, in this study we focus on evaluating the impact of the reform on formal employment. Although the effects of changes in payroll taxes have already been studied in the Colombian context, it is important to study the effects of this particular reform for two reasons. First, the effects of 
changes in payroll taxes are likely to be asymmetric depending on whether there is a hike or a decline. Due to a binding minimum wage, it is more feasible for a reduction in payroll taxes to be passed-through to employees as higher wages than for an increase in payroll taxes to be passedthrough to employees as lower wages. On the other hand, changes in the tax rate would have larger effects on employment if the levied taxes were used to finance services that do not directly benefit contributors and that, as a result, cannot be passed-through to workers' wages.

In Colombia, the link between benefits and contributions was relatively weak before the introduction of Law 1607. This made workers less willing to accept the lower wages offered by employers in response to increases non-wage labor costs. As Kugler and Kugler (2009) show this implies that there is less formal employment and, consequently, it becomes harder to find a formal sector job. Kugler and Kugler (2009) provide evidence that reductions in payroll taxes often proposed to stimulate demand for low-wage labor - are an effective measure to reduce unemployment and informality among young and low-skilled workers, especially if the tax cuts are focused on indirect benefits (like SENA and ICBF).

The analysis in this paper examines the effects of Law 1607, which reduced payroll taxes for those with less than 10 minimum wages and for self-employed who hired two employees or more. These two groups that qualify for payroll tax reductions under the reform. The analysis exploits the fact that specific groups of employers and employees were affected by the reform to estimate the impact of the reduction in the payroll tax using a quasi-experimental evaluation design. The analysis consists of comparisons of the following two pairs of groups: (i) workers with fewer and more than 10 minimum wages, before and after the reform; and (ii) selfemployed workers with two or more employees, and others who either are not self-employed or who are self-employed but hire fewer than two employees, before and after the reform. 
Our analysis uses three different data sets to examine the effects of the reform. In particular, we analyzed data from: the Household Surveys collected by the Colombian National Department of Statistics (Gran Encuesta Integrada de Hogares or GEIH, in Spanish), administrative data from the Social Security System (Planilla Integrada de Liquidación de Aportes or PILA, in Spanish), and survey data from the Monthly Manufacturing Sample (MMS). The data from the Household Surveys and from the Social Security records enable us to examine individual-level data to analyze effects on levels and transitions to the formal sector. The data from the MMS allow us to examine the effects of the reform on permanent employment at the establishment-level.

The results from the three data sets consistently show positive effects of the reform on formal employment. The results from the Household Surveys show an increase of 8.5 percentage points or a 15 percent increase in the probability of having a signed contract, and an increase of 12.4 percentage points or a $32 \%$ increase in the probability of contributing to the pension and/or health schemes for those with less than 10 minimum wages after the reform. The effects are bigger among smaller companies. Likewise, the results using Social Security records show an increase of 3.5 percentage points or 15.2 percent in the probability of going from informality or unemployment to formality for those paid under 10 minimum wages after the reform.

The results also show small positive effects for self-employed workers with more than three employees using both the Household Survey and Social Security data. The probability of employment and of transitioning to a job with health benefits and/or pensions increases by one and sixteen percentage points after the reform for self-employed workers with more than three employees. 
The results using the Manufacturing Sample also show that the reform increased permanent employment in the manufacturing sector. The evidence shows that manufacturing establishments that pay less than 10 minimum wages on average increase their number of permanent employees by 46 workers. They also show that the percentage of permanent workers employed by those establishments increased by 10 percent following the reform. In general, the reform is associated with an increase in formal employment for individuals and for companies with less than 10 minimum wages after the reform. The effects are robust to different specifications and are greater among smaller companies.

\section{Changes in the Structure of Payroll Taxes}

About four years ago, Colombia introduced important legislative changes to reduce payroll taxes. The most important reform in changing payroll taxes since the reforms of the 1990s was the introduction of Law 1607. This reform reduced payroll taxes for workers with low wages, who a priori should had experienced greater distortions and had fewer formal job opportunities due to the higher labor costs before the reform.

A couple of years before, in 2010, the First Employment Law reduced payroll taxes for employers hiring young workers and others entering the labor force. As a result, in this analysis we try to distinguish the First Employment Law effects from those of the more expansive reforms introduced by Law 1607.

\subsection{Law 1607 of 2013}

The tax reform introduced with Law 1607 included exemptions to employer payroll taxes used to finance training programs, family and childcare programs, and compulsory health benefits. While the law was approved in 2012, starting on May $1^{\text {st }}, 2013$, exemptions were first 
applied to the contributions going to training programs (SENA, 2\%) and family and childcare programs (ICBF, 3\%), for a total exemption of 5\% in payroll taxes. Importantly, neither training nor family and childcare programs are typically used and benefit all of those who contribute payroll taxes to these programs, so the link between the benefit and the contributions made to these programs is weak.

Beginning on January $1^{\text {st }}, 2014$, the exemptions were also applied to employer contributions to the Contributory Health Scheme (of 8.5\%), first introduced in 1993 by article 204 of Law 100. In our analysis, we evaluate the differential impact on formal employment for workers exempted and not exempted from taxes by the new law starting in 2013.

According to Law 1607, issued by decree 862 in April 26, 2013, the exemption on payroll taxes applies to two groups of individuals. First, it applies to all legal, contributing forprofit entities paying taxes and that have in their payroll workers who individually accrue fewer than ten (10) monthly, legal, minimum wages. Second, it applied to all self-employed individuals who employ two or more workers. The law also indicates those individuals who do no benefit from the exemptions. These include legal entities that do not pay income taxes, such as unions, community action boards, horizontal joint ownership boards, and, in general, those listed in articles 22, 23, 23-1, and 23-2 of the National Tax Code. It also includes legal, non-profit entities, such as cooperatives, employee funds, associations, corporations, and foundations. In addition, it includes Free Tax Zones established by December 31 ${ }^{\text {st }}, 2012$ or with pending applications at that time as well as users of previous Free Tax Zones that have qualified or could qualify in the future to these zones and that are subject to the special income tax rate of $15 \%$ established by the first subsection of article 240-1 of the National Tax Code. Finally, it includes 
all employees who earn more than 10 minimum wages and self-employed individuals who employ fewer than two employees.

At the same time, the Colombian government introduced its Plan to Increase Productivity and Employment or PIPE program (Plan de Impulso a la Productividad y el Empleo in Spanish), which intended to replace the revenues lost from the exemptions for SENA, ICBF and public health insurance through other sources of funding. To off-set the revenue losses from the exemptions, the tax reform included an equity income tax or CREE (Impuesto sobre la Renta para la Equidad in Spanish). The CREE rate was 9\% starting in 2013. In 2015, the CREE increased by an additional 5\%, which has continued to increase by 1\% every year until 2018 . This percentage is distributed as follows: 1.4 percentage points go to SENA, 2.2 percentage points go to ICBF, and 4.4 percentage points go to the social security health scheme. The additional 1.2 percentage point charged during the first three years was devoted to financing public institutions of higher education (40\%), the subsidized health scheme (30\%), and social investments in the agricultural sector (30\%). Importantly, the equity income tax is levied on profits and, thus, tends to affect the most profitable firms, which are also the largest firms.

In conclusion, beneficiaries of the payroll tax exemptions instituted by Law 1607 from 2012 are CREE contributors who hire workers with less than 10 minimum wages and selfemployed individuals who hire two or more workers. The reduction of the employer payroll tax rates for SENA and ICBF by $5 \%$ and of health contributions by $8.5 \%$ introduced by the reform intends to not only reduce informal employment, but also to generate new formal jobs. The reason why employment creation in the formal sector would be incentivized is that payroll taxes which are associated with formal employment would fall. Even though the equity income tax 
was introduced, this tax is on profits and not associated with employment thus de-linking the new taxes from employment.

\subsection{Law 1429 from 2010}

Before the implementation of the Tax Reform, the First Employment Law was introduced in 2010. This reform also reduced the labor costs generated by payroll taxes to certain types of recently hired workers.

The First Employment Law allows companies to deduct from their income tax contributions the payroll tax payments destined to finance services not directly benefiting all their employees, including tax contributions to finance SENA, ICBF, as well as contributions to the Solidarity Guarantee Fund or FOSYGA (Fondo de Solidaridad y Garantias in Spanish), which subsidizes health services for the poorest, and the contributions to the Minimum Pension Guarantee Fund or SGP (Sistema General de Pensiones in Spanish) which subsidizes pensions for the poorest. These deductions applied to companies that hired: workers younger than 28 years of age; female heads of households; individuals who have been displaced or are in the process of reintegration; individuals who are disabled; women older than 40 years of age, and workers earning less than 1.5 minimum wages. Although this law also covers pensions, the First Employment Law is more limited in the number of individuals it covers relative to the payroll tax reform. This is because it is only valid for new hires covering young workers, women over 40, and those who earn less than 1.5 times the minimum wage, as opposed to the 10 minimum wage threshold in the tax reform.

In addition, the benefits only apply to new workers. The law defines new workers as those who appear for the first time in the administrative social security records, or those who 
were previously in the system as self-employed workers. This prevents companies from trying to claim exemptions for workers who are laid-off and rehired or new hires who are simply replacing previously hired workers.

To benefit from the exemptions of Law 1429, employers must also fulfill the following requirements established by the law. Companies have to be formally registered and have to hire the type of workers described by the law. Also, they have to increase their payrolls and not replace old personnel. That is, the number of employees must increase relative to the number of employees that were contributing in the previous year, and the total value of payroll must increase by the month of December of the previous year in which the discounts are applied.

In the empirical analysis presented in this paper, we will focus on the impacts of the Tax Reform (Law 1607) by exploiting the fact that the reform covered certain groups but not others. Moreover, we will attempt to disentangle the effects of the tax reform from those of the First Employment Law (Law 1429) since the latter preceded the tax reform and some of the coverage of the latter may have overlapped somewhat with Law 1607.

\section{Data}

\subsection{Household Surveys}

Colombia collects cross-sectional data on labor force participation, earnings, and quality of life indicators of households since the 1960s. However, since the start of this data collection process and up to 2006, data were only available for 13 cities and their metropolitan areas. Starting in 2006, the entire survey covers 24 cities and their metropolitan areas. In addition, the modules on labor markets and household earnings also cover rural sectors. 
The purpose of this data collection effort is to provide information about the size and structure of the labor force (employed, unemployed, and inactive) as well as of sociodemographic characteristics of the population. Consequently, the Household Surveys allow to classify the population according to the concepts detailed by the International Conference of Labor Statisticians (CIET, in Spanish); to calculate the main labor market indicators (participation rate, occupation rate, unemployment rate, etc.); to measure general population characteristics (characteristics of dwellings, access to public services); to obtain sociodemographic information from the population (sex, schooling levels, civil status, etc.), and to measure employment characteristics, among others.

The existing database is the result of a probabilistic sampling of several stages, stratified by unequal conglomerates, and weighed for the 24 capital cities and their metropolitan areas. The universe is the entire civilian, non-institutionalized population residing in Colombia. The sampling unit is a segment of 10 contiguous households. The sample size is 20,669 households. The sampling error is no greater than $5 \%$ and possesses national coverage, including differentiation by zone, department, and large regions. Data were collected weekly for big cities and monthly for capital cities.

In order to construct the treatment group that was exempt because they earned less than 10 times the minimum wage, we calculated a variable called Times Minimum Wage (MW) as the ratio of nominal yearly earnings to the yearly minimum wage $(515,000$ Colombian pesos for 2010; 535,600 Colombian pesos for 2011; 566,700 Colombian pesos for 2012; and 589,500 Colombian pesos for 2013). We, then, used this variable to construct a dummy for 10 times the MW. We also constructed variables for: self-employment; employers; contract type for wageearners. We also construct firm size variables that identify if firms are less than 3 employees; 
between 4 and 10; between 10 and 50, and more than 50 employees. This allows us to construct an indicator for the second treatment group by interacting the self-employment dummy with the less than 3 employee dummy. We also created an indicator for 2013 to capture the effects of the reform by interacting the post-reform period with the indicators of whether workers earned less than 10 times the MW and whether they were self-employed and hired at least two employees.

For the dependent variables, we constructed several measures of formality. In particular, we constructed five different measures of formality: an indicator that takes the value of 1 if the employee has a written contract and zero otherwise; an indicator that takes the value of 1 if the employer or employee contributed to social security and zero otherwise; an indicators that take the value of 1 if the employer or employee contributed either to the health system, pensions, and workers' compensation and zero otherwise.

Among the control variables, we include data on socio-economic factors about individuals, such as age, age squared, marital status, whether the person is literate (i.e., can read and write), years of schooling, department dummies, and year dummies among others.

Finally, to corroborate the robustness of the results, we create additional variables to generate placebos by replacing some criteria, and controls for the First Employment Law. In particular, we generated a variable for fewer than $20 \mathrm{MW}$, as well as variables for individuals younger than 29 years of age, women older than 40 years, and for individuals with salaries below 1.5 MW in order to control for the First Employment Law.

Table 1 shows different measures of formality for the years from 2010 to 2013. The table shows that formality has increased over time, regardless of the measure used. For example, the proportion of people who contribute to health or pension schemes or both increased by $30 \%$ in 
2010 to $33 \%$ in 2013. Similarly, the proportion of people contributing to workers compensation increased from $28 \%$ in 2010 to $31 \%$ in 2013 . The proportion of individuals with a written contract from $29 \%$ in 2010 , to $31 \%$ in 2013 . Table 1 also shows that the coverage of the reform was broad, since $99.5 \%$ of workers in 2012 (the year that the reform was approved) earned less than $10 \mathrm{MW}$. Also, $22 \%$ of individuals were self-employed workers and $6 \%$ were self-employed with more than 2 employees in 2012. Finally, over half of the individuals in the sample, 59\%, are men; about 55\%, are married or have lived with their partner for more than two years; $56 \%$, have a high school degree while a minority of them has no high school or university degree in 2013.

\subsection{Social Security Administrative Records}

The social security records come from the PILA, which is the data that integrates all the payroll contributions made by workers. These records contain contributors' reported information for each of the funds in which they are required to contribute. It is the responsibility of the contributor to provide information in order for the contributions to be paid by the Social Security System.

The PILA database analyzed in this study has around 1.25 billion registries that reflect the tracking of 16.8 million individuals over 7 years (from 2008 through 2014). The data has no defined periodicity, since they are based on the contribution reports to the health and pension systems made by individuals at any point in time during the period from 2008-14. This means that a person may register more than one monthly payment to the same fund and that the number of days quoted in a month can be greater than the duration of the month.

For this analysis, we consolidated all the payment reports and quoted days for each fund in each month. The total monthly income was converted to constant December 2014 prices using 
the monthly inflation rate for each department. This was then used to estimate the number of times a person earns the minimum wage. In addition, the database contains reports from the contributing company and reports related to employees. Using this code, we added individuals who reported monthly for one company and used this to infer the firm size. The database has no information regarding date of birth or age for individuals before 2014, so we did not consider these characteristics. The control variables were constructed for each month, year, type of industry, and department.

We consider workers who have a payment report as being in the formal labor market at that moment in time. Thus, we estimate transitions from non-employment to formal or registered employment as those in which an individual was not in the system the previous month and then appears as contributing into the system the next month. The results of contributions to the health and pension funds are very similar, but there is a possibility of registering payments to the health scheme without actually working. For this reason, we rely only on registries into the pension funds to identify transitions into formal employment. ${ }^{3}$

The analysis includes an unbalanced panel by individual year-month. Consequently, some of the controls and added periods do not contain any information. These are considered as additional categories in the fixed effects.

Table 2 shows the descriptive statistics for the PILA database for the entire sample and by company size. The proportion of employees transitioning from outside the labor force, unemployment, or informality towards formality or the fraction of individuals who enter into registered employment is, on average, about $23 \%$ per month. The average size of registered

\footnotetext{
${ }^{3}$ Estimations were made using $25 \%$ of the sample due to the volume of information.
} 
companies in the PILA database is of 840 employees. This table also shows that formal employment is concentrated in the capital (Bogota with 5.25\%) and the two departments where the next largest cities of the country are located are located (Antioquia with 5.1\% and Valle with 3. $4 \%)$.

\subsection{The Monthly Manufacturing Sample (MMS)}

The MMS includes data on employment, wages, production, and characteristics of establishments in the manufacturing sector, i.e., those with Industry Code CIIU Rev. $3{ }^{4}$

The data of the MMS are used to detect changes that could occur in the manufacturing sector in the short-term, including changes in employment, wages, hours worked, production, and sales of Colombian manufacturing establishments. At the same time, the sample allows to determine the performance of the sector in different industrial activities; to determine the size and evolution of different sectors; to create competiveness indices; to analyze the impact of the economic dynamics on the productive sector; and to construct an index to temporarily estimate GDP.

Each establishment's information is given to DANE (the National Administrative Statistics Department) by the accountant, manager, owner, or the person in charge of accounting matters in the establishment. The MMS uses as sampling, observation, and analysis unit the industrial establishment and it is part of the Annual Manufacturing Sample with a 5\% error rate

\footnotetext{
${ }^{4}$ This dataset dates back to May 1962, when the country started compiling industrial sampling data in order to build employment and wage indicators. In parallel, the country also collected data on industrial production, an effort that was stopped in 1970 when the data collection process was unified under a single system, using code ISIC Rev. 1. This design was in use until 1980. Nevertheless, the first change in the data collection process took place in 1978 when the design of the sample was modified in order to comply with code ISIC Rev. 2. This design was maintained until 1990. At the same time, during the most recent years of the $1980 \mathrm{~s}$, a new adjustment to the design was introduced and was maintained until the end of the millennium. Towards the end of the 1990s and beginning of the $21^{\text {st }}$ century, changes in representativeness and the need to adopt a third revision of the ISIC motivated the adoption of the current design.
} 
at the national level. It includes stratified probabilistic sampling (although random for each stratum), and stratification is done by production, personnel, and type of industry. The compilation of the information is performed within the first 20 days of each month.

These data are subject to confidentiality restrictions and statistical reserve. Although we had access to the data through DANE's computers, it is not possible to get access to these data outside of the country. For this reason, the descriptive information we obtained from the database is limited. One of the reasons for such confidentiality is that for a given region, a company that meets certain characteristics (for instance, size, production, and type of industry) may be the only company that does so and, as a result, confidentiality would be lost. Confidentiality is one of the main agreements with the companies providing information.

In this study, we use the MMS to examine the impacts of the reform on employment and hours worked of different types of workers in the manufacturing sector. The data to which we had access has about 120,770 entries (about 16,400 annual entries). The database we used had information on the establishment characteristics previously mentioned as well as monthly temporary jobs from January 2007 through April 2014. Even though there is an identifying number that may seem unique, it is not possible to do a panel-like tracking because oftentimes the response of each unit is voluntary and it is sometimes forcefully imputed because of probabilistic matters.

We constructed several variables with the MMS for analysis. Unlike the Household Surveys and the Social Security data, the MMS does not have individual level wages. We can, however, estimate the ratio of the average wage in the establishment to the MW of 515,000 in 2010 Colombian pesos. Then, we estimate a dummy variable for establishments whose average wages are less than 10 times the MW to identify establishments in which employees are most 
likely affected by the payroll tax reform. Our outcomes are the total number of the total number of production and non-production permanent employees and the proportion of permanent production and non-production workers out of the total number of employees (both permanent and temporary). The idea is that permanent employment should increase both in levels and as a proportion of total employment, since payroll taxes are required for permanent workers but sometimes exempt temporary workers. We also examine the impact of the reform on the number of hours worked by permanent employees. Since the fixed cost of hiring a permanent worker goes down, employers should now prefer hiring more permanent workers and reducing their hours worked. We also construct a placebo of fewer than $20 \mathrm{MW}$, to check that our results are driven by the reform and not by some other factor that affects firms paying lower wages.

Table 3 shows descriptive statistics for the data from the MMS. The average number of permanent non-production and production employees in the sample are 52.2 and 99.5 employees, respectively. The average number of yearly regular and extraordinary hours worked for permanent production and non-production employees are 19,587 and 1,725, respectively.

Figure 1 shows the distribution of establishments by department. The vast majority of manufacturing establishments are in Bogota, Antioquia, and el Valle; the rest of the establishments are distributed throughout the country. Bogota has $32.9 \%$ of the establishments and $7.3 \%$ are located in Cundinamarca (a department next to Bogota); $21.4 \%$ are in Antioquia; $12.8 \%$ are in el Valle; $6.3 \%$ are in the Atlantic (in the Caribbean coast) and $3.4 \%$ are in Santander. The rest are distributed throughout the country with no more than $2.5 \%$ of the establishments located in any one of the other departments. 


\section{Empirical Evidence}

We explore empirically whether the reduction and restructuring of payroll taxes generated incentives to create formal jobs. We also evaluate if the reform increases employment at the extensive margin (number of employees) and reduces employment at the intensive margin (number of hours) using data at the individual-, household- and establishment-level.

\subsection{Results from the Household Surveys}

We estimated the following model to calculate the probability of having a formal job using data from the Household Surveys:

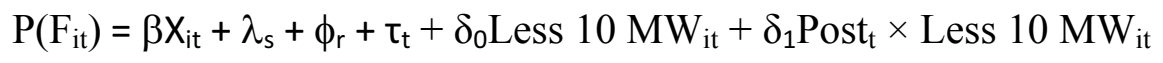

$$
\begin{aligned}
& +\delta_{2} \text { Post }_{\mathrm{t}} \times \text { Self-Employed_More } 3 \text { Employees }_{\mathrm{it}}+\mathrm{u}_{\mathrm{it}}
\end{aligned}
$$

Where $\mathrm{P}\left(\mathrm{F}_{\mathrm{it}}\right)$ is the probability of having a formal employment and where formal employment is equal to one if the individual has a formal job defined as: (a) having a written contract, (b) the individual or employer pays for health benefits, (c) the individual or employer contributes to a pension fund, (d) the individual or employer contributes to a health and/or pension scheme, and (e) the individual or employer pays for workers' compensation. Less 10 $\mathrm{MW}_{\text {it }}$ is a dummy variable that equals one if the person receives fewer than 10 minimum wages. Self-Employed More 3 Employees $_{\text {it }}$ is an indicator that equals one if the employee is selfemployed and hires three or more workers. ${ }^{5}$ Post $t_{t}$ is an indicator for whether the person is observed after 2013. Thus, the coefficients on the interaction terms, $\delta_{1}$ and $\delta_{2}$, capture the effects of the reform on formal employment. $\mathrm{X}_{\mathrm{it}}$ is a vector of controls that includes characteristics such as age, marital status, gender, schooling level, firm size, and an indicator for whether the

\footnotetext{
${ }^{5}$ Note that the data does not allow distinguishing 2 or more employees, so we construct a variable for three or more employees.
} 
employee is self-employed or not as well as interactions between this last indicator with firm size. The sectorial, geographic, and temporal effects are captured by $\lambda_{\mathrm{s}}, \phi_{\mathrm{r}}$ and $\tau_{\mathrm{t}}$, respectively. We cluster standard errors by department.

Table 4 reports coefficients $\delta_{1}$ and $\delta_{2}$, which capture the effects of the individuals with fewer than 10 minimum wages and on self-employed with more than 2 employees. The results show that the reform generated an increase in the probability of having formal employment. Specifically, the probability of having a written contract after the reform is 8.5 percentage points greater for employees with wages less than $10 \mathrm{MW}$. The probability of contributing to health benefits is 13.4 percentage points higher. The probability of contributing to a pension scheme increased by 11.1 percentage points and the probability of contributing to a health and/or pension system increases by 12.4 percentage points for workers with fewer than ten MW after the reform. Finally, the probability of contributing to workers' compensation increases by 17.1 percentage points. These coefficients are robust and are significant even with clustered standard errors. To understand the magnitude of these effects, we estimated the elasticity of employment with respect to non-wage labor costs. The effects translate into elasticities of 3 and 4.2 for the effects regarding written contracts and jobs that contribute to social security. These effects are in line with the biggest effects reported by Hamermesh (1996) and similar to those observed in countries like Germany, where labor costs are similar to those of Colombia and where wages are downwardly rigid.

Table 4 also reports coeffficients of the post-reform indicator interacted with the indicator for self-employed workers with 3 or more employees. The results show that the probability to pay for health benefits or to contribute to a health or pension fund increases by one percentage point among self-employed workers with more than two employees after the reform. This effect 
translates into an elasticity of employment of 0.3 , which is much lower than the elasticity we calculated for workers with less than 10 minimum wages, but it is within the average range of elasticities found by Hamermesh (1996).

When the effects are estimated separately for men and women, it is clear that while the effects for those with less than 10 minimum wages are observed for both men and women, the effects for the self-employed with more than 3 employees is only observed for men. Panel B of Table 4 shows the effects for women and Panel $\mathrm{C}$ for men. The results for those earnings less than $10 \mathrm{MW}$ are greater for women and they are observed across all measures of formality. For example, the probability of having a written contract increases to 9.3 percentage points while the probability of contributing to either health or pension benefits increases to 15 percentage points for women earning more than $10 \mathrm{MW}$ after the reform. The results in Panel $\mathrm{C}$ shows equivalent effects on these measures of formality of 7.8 and 8.2 percentage points for men. However, the effects on the probability of contributing to a pension plan or workers' compensation are not significant for men. By contrast, there is no effect on self-employed women, but the effect of the reform increases the probability of contributing to the health insurance system for self-employed men with more than 2 employees.

Table 5 shows the results of the effects of the Tax Reform by firm size. The results show that Law 1607 had greater effects on formal employment among those working in the smallest firms. Panel A report estimates for the full sample; Panel B report estimates for those in firms with fewer than 10 employees; Panel C report results for firms between 11 and 50 employees, and Panel D report results for those in firms with more than 50 employees. The effects for those working in firms with fewer than 10 employees are larger than those for the entire sample. The probability of having a formal job under any of our definitions of formality increases by about 
six percentage points for self-employed workers with more than 3 employees and by about 230 percentage points for those with less than 10 minimum wages. The effects for workers with less than 10 minimum wages and who work in firms with 10 to 50 employees are significant and bigger than those in the entire sample, but smaller than those found for small firms with fewer than 10 employees. Formality among men and women earning less than 10 minimum wages in medium-sized firms increased between 22 to 30 percentage points, but there is no effect among self-employed workers in medium-sized firms. By contrast, formality among workers earning less than 10 minimum wages in firms with more than 50 employees increased between 2.5 to 5 percentage points after the reform, which are smaller effects than those found in the full sample. This reveals an obvious pattern. The effects are bigger among those in smaller firms. This makes sense given that bigger firms were more likely to have to pay the CREE and smaller firms are more likely to have qualified for exemptions for employees closer to the MW and for selfemployed hiring others.

To guarantee that these results capture the effects of the reform and not some other factors affecting lower-earning workers after the reform, we performed regressions with placebos. In our placebo, we changed the threshold of ten MW (as specified by Law 1607) to 20 MW in order to calculate the dummy variable for employee wages. In these regressions, we excluded all workers with fewer than $10 \mathrm{MW}$. Table 6 shows these results with clustered standard errors. We found that there was no effect on formality for people with fewer than 20 MW. As can be observed on Table 6, in many cases the coefficients become negative and they were always insignificant.

Finally, Table 7 shows similar effects to those presented in Tables 4 and 5, but controlling for effect on groups affected by the First Employment law. In particular, we included 
indicators for individuals younger than 29 years of age, women older than 40, and individuals earning less than 1.5 MW and we interacted them with a post-2011 indicator, since the First Employment Law was enacted in December 2010. These results show that the effects of the interaction between the reform and employees with less than $10 \mathrm{MW}$ is still positive and significant and that the effect is even greater when controlling for the First Employment Law. In this case, the probability of having a formal employment increases by about 22 to 25 percentage points. The effects for people younger than 29 years and for those who earn less than $1.5 \mathrm{MW}$ after 2011 are either statistically or economically insignificant. On the other hand, the effects for self-employed workers with more than two employees after the tax reform and among women older than 40 after the First Employment law are now negative and significant.

In conclusion, people earning less than 10 minimum wages benefited the most from the reform in terms of having a higher likelihood of holding a formal sector job and the effects are greater for women and for workers in small firms.

\subsection{Results from Social Security Records}

We estimated the following model to calculate the impact of the reform on transitions from unemployment, inactivity, and informal employment into registered employment:

$$
\begin{aligned}
& \mathrm{P}\left(\mathrm{F}_{\mathrm{it}}\right)=\beta \mathrm{X}_{\mathrm{it}}+\lambda_{\mathrm{s}}+\phi_{\mathrm{r}}+\mathrm{\tau}_{\mathrm{t}}+\mu_{\mathrm{m}}+\delta_{0} \text { Less } 10 \mathrm{MW}_{\mathrm{it}}+\delta_{1} \text { Post }_{\mathrm{t}} \times \text { Less } 10 \mathrm{MW}_{\mathrm{it}} \\
& +\delta_{2} \text { Post }_{t} \times \text { Self-employed More } 3 \text { Employees }_{i t}+u_{i t}
\end{aligned}
$$

$\mathrm{P}\left(\mathrm{F}_{\mathrm{it}}\right)$ is the probability of transitioning from non-employment or informal employment into the formal sector. Less $10 \mathrm{MW}_{\text {it }}$ and Self-employed More 3 Employees are indicators for groups exempted from the payroll tax, that is, those with less than 10 minimum wages and selfemployed workers with two or more employees. Post $t_{t}$ is an indicator for whether the company is 
observed after 2013. $X_{\mathrm{it}}$ includes economic activity and size of the firm. The PILA database does not contain data on age, education, or any other individual characteristic. The geographic and sectorial effects are captured by $\lambda_{\mathrm{s}}$ and $\phi_{\mathrm{r}}$ respectively and the year and month effects are captured by $\tau_{\mathrm{t}}$ and $\mu_{\mathrm{m}}$. All of the regressions estimate clustered standard errors at the individual level.

Table 8 shows the effects on transitions into registered jobs for the full sample and by firm size. Columns (1) and (2) show the coefficients for the interaction terms in regressions using the full sample. Columns (3) and (4) show the estimates for firms with fewer than 3 employees, Columns (5) and (6) show the estimates for firms between 3-10 employees; Columns (7) and (8) show the estimates for firms between 10-50 employees and Columns (9) and (10) show the estimates for firms with more than 50 employees. The overall results in Column (1) show an increase in the probability of transitioning into formal sector employment of 3.5 percentage points among employees with less than 10 minimum wages and of 16.3 percentage points among self-employed workers employing more than 2 employees. The specification in Column (2) allows for differential effects for those earnings less than $2 \mathrm{MW}$, those earnings between 2 and 5 MW and those earning between 5 and $10 \mathrm{MW}$. As expected, these results show that the impact is greatest on those earning close to the MW and smaller for those with higher wages. The probability of transitioning into formal employment increases by 5.1 percentage points for those earning less than $2 \mathrm{MW}$, by 2 percentage points for those earning between 2-5 MW and by 1 percentage point for those earning between 5-10 MW. Since it is more difficult to pass on higher payroll taxes onto workers when workers face a binding minimum wage, it is likely that a reduction in payroll taxes also has the greatest impact in terms of formal employment for this group of workers. 
Columns (2)-(10) of Table 8 show the effects on entry into registered jobs for firms of different sizes. Columns (2) and (4) show that the likelihood of transitioning into registered employment increases by 39.4 and 29.7 percentage for those in firms with fewer than 4 employees and in firms with 4 to 10 employees who earn less than $10 \mathrm{MW}$ after the reform. Also, Columns (3) and (5) show that the effects are bigger for those earning less than $2 \mathrm{MW}$, somewhat smaller for those earning between 2-5 MW and even smaller, though still positive and significant, for those earning between 5 and $10 \mathrm{MW}$. The effects are negative for those in larger firms. Likewise, the likelihood of transitioning into registered employment increases by 11.7, 6 and 7.5 percentage points for self-employed workers with 4 to 10 employees, with $10-50$ employees and with more than 50 employees.

\subsection{Results from the Manufacturing Survey}

We estimated the following model to calculate the impact of the reform on the level and composition of employment using the monthly manufacturing sample:

$$
\mathrm{E}_{\mathrm{jst}}=\alpha \mathrm{K}_{\mathrm{jst}}+\lambda_{\mathrm{s}}++\phi_{\mathrm{r}}+\Psi_{\mathrm{t}}+\delta_{0} \text { Less } 10 \mathrm{MW}_{\mathrm{jst}-1}+\delta_{1} \text { Post }_{\mathrm{t}} \times \text { Less } 10 \mathrm{MW}_{\mathrm{jst}-1}+\mathrm{v}_{\mathrm{jst}}
$$

$\mathrm{E}_{\mathrm{jst}}$ is employment in establishment $\mathrm{j}$ for permanent production and non-production employees, as well as the percentage of permanent production and non-production employees. Less $10 \mathrm{MW}_{\text {jst-1 }}$ is a dummy variable that equals one if the establishment pays on average wages that are less than ten minimum wages before the reform. Post $t_{t}$ is an indicator for whether employment at the company occurs after May 2013. The geographic, sectorial, and temporal effects are captured by $\lambda_{\mathrm{s}}, \phi_{\mathrm{r}}$, and $\Psi_{\mathrm{t} .} \mathrm{K}_{\mathrm{jst}}$ represents installed capital. All of the standard errors are clustered by department. 
The coefficients of interest are those for the interaction between the variable for less than 10 minimum wages and the variable for after 2013 for the different types of workers. Panel A in Table 9 shows the results for the entire sample, while Panels B, C, D, and E in the same table show the results for establishments with less than 4, 4-10 employees, 10-50 employees, and more than 50 employees, respectively. Columns (1) and (2) in Table 9 report the impacts on the number and percent of permanent non-production employees, Columns (3) and (4) reports impacts on the number and percent of permanent production workers. For establishments that pay on average less than 10 minimum wages, we observed an increase in the number of permanent workers and employees after 2013. In particular, Columns (1) and (3) in Panel A show that there is an increase of 46.1 permanent non-production employees and of 254 permanent non-production employees in establishments that pay less than 10 minimum wages after the reform. This by itself suggests increased job creation in the manufacturing sector. In addition, Columns (2) and (4) of Panel A show an increase of $10 \%$ in the share of permanent non-production employees, though no effect on the share of permanent production employees.

Columns (5) and (6) in Table 9 also show the effects on regular and extraordinary hours for all permanent workers. The results in Column (5) show substitution in working hours for permanent employees. There is a reduction of 279 regular hours or a reduction of $1.5 \%$ in regular hours for this group of workers, though no effect for extraordinary hours.

Panels B-E in Table 9 show effects by establishment size. The results show that even though the effects regarding additional permanent workers are naturally smaller in smaller establishments, the effects are clearly larger for smaller companies when looking at the shares of permanent workers. Panels B and C in Table 9 show that the percentage of permanent nonproduction employees increases by 85.8 and 55.5 percent, respectively, in establishments with 
fewer than 4 employees and in companies with 4 to 10 employees and that pay less than 10 minimum wages on average. Likewise, for small companies that pay less than 10 minimum wages on average, there is an increase in the percentage of permanent production workers. Also, there is a reduction in the regular and extraordinary working hours of permanent employees in establishments with less than 4 employees and a reduction in regular hours in establishments with 4-10 employees. By contrast, Panels D and E Table 9 show that while there is a positive effect on the number of permanent non-production and production employees, there are no effects on the shares of permanent non-production and production employees or on regular and extraordinary permanent hours among bigger establishments with 10 to 50 employees and with 50 or more employees. Thus, consistent with the data using the Household Surveys and the Social Security records, we find bigger effects on smaller employers. This is likely because the smaller employers are more likely to face higher labor costs due to the inability to pass these costs to their employees. Also, the equity income tax introduced by the Tax Reform likely had a higher incidence on larger employers.

As with the Household Surveys, we carried out regressions with a placebo group using the MMS data. Table 10 shows the results of this placebo using as a threshold 20 minimum wages on average at the establishment-level. The results show no significant effects in the regressions that use $20 \mathrm{MW}$ as a threshold.

\section{Conclusions}

The results of estimations using data from Household Surveys, the Social Security records, and the Monthly Manufacturing Sample are consistent with an increase in the creation of formal employment in response to the Tax Reform that eliminated payroll contributions for training, family services and health benefits. 
In the case of regressions using data from the Household Surveys and the Social Security records, there is strong evidence indicating a greater propensity towards formality among the two groups who experienced payroll tax reductions due to the reform, i.e., those with less than 10 MW and self-employed with more than 2 employees.

The analysis with the data from the Household Surveys and the data from the Social Security records show similar effects on formal employment with contributions to pension funds. The Household Surveys show an impact of 11.1 percentage points on the likelihood of being employed jobs with contributions to pension funds for those with less than 10 minimum wages. The Social Security data shows an increase of 3.5 in the likelihood of transitioning to employment registered in a pension fund. The results from the two databases also show effects of one percentage point on formal employment among self-employed workers with more than two employees. The Household Surveys also show an increase of 1 percentage point in the likelihood of being employed in a job with contributions to both health and pension plans for self-employed workers with more than 2 employees. Likewise, the Social Security data shows an increase of 16.3 in the likelihood of transitioning into a job registered with pension contributions.

Moreover, the results using the Household Surveys and Social Security records show that small firms are the ones most likely to respond to the reform by creating formal jobs. Moreover, the results using the Social Security records are also stronger for those who earn lower salaries closer to the minimum wage. We also included placebo regressions to verify that the results were not driven by the reform and not by other factors. We do a placebos including interactions with less than $20 \mathrm{MW}$ instead of $10 \mathrm{MW}$ and the results show no effects. The fact that the placebo group was not affected, and that the groups most likely to be affected are indeed the ones for which we find greater effects, confirms that the results are likely driven by the reform. 
The Manufacturing Sample results confirm these results and show an increase in permanent employment. These results show an increase in the number and proportion of permanent production and non-production employees after the reform among establishments that pay less than 10 minimum wages on average. The Tax Reform also caused a substitution in the regular hours worked by permanent workers, as would be expected since the costs of hiring permanent workers decreased. As with the individual-level results, establishment-level results show that the Tax Reform had greater impact among companies with fewer than 10 employees.

These effects are larger in comparison to the reform from the mid-nineties in Colombia. Kugler and Kugler (2009) find a much smaller effect - a 10\% percent increase in payroll taxes reduced employment by about $5 \%$. The results from the MMS, which are closest to those used by Kugler and Kugler (2009), show that a decrease of $13.5 \%$ in payroll taxes introduced by the reform increased the share of permanent non-production workers by $46 \%$.

At the same time, the effects are substantial compared to other reforms carried out in Colombia affecting both the supply and demand of labor. On the demand side, the exemptions introduced by the First Employment Law for new hires from specific groups do not appear to be as effective as the exemptions introduced by the Tax Reform. On the supply side, the program Youth in Action (or Jóvenes en Acción in Spanish), which provided vocational training and internships to young individuals, increased formal employment among men and women by 6 and 7 percentage points, respectively. In this case, the cost per employee was $\$ 770$ dollars. In comparison, the tax reform probably generated fewer costs, since the funds lost due to the tax exemptions were recovered through the equity income tax. On the other hand, Kugler et al. (2015) find that the effects of the Youth in Action program were permanent. It is too early to 
know if the effects of the Tax Reform are long-term, but it is possible that entering the formal sector can generate hysteresis and increase the probability of remaining in the formal sector. 


\section{References}

Bell, Linda. 1997. "The Impact of Minimum Wages in Colombia." Journal of Labor Economics 15, no. 3, suppl.: S102-S135.

Blau, Francine, and Lawrence Kahn. 1999. "Labor Market Institutions and Economic Performance." In Handbook of Labor Economics, vol. 3, ed. Orley Ashenfelter and David Card, 1399-1461. New York: Elsevier.

Gordon, Robert. 1972. "Wage-Price Controls and the Shifting Phillips Curve." Brookings Papers on Economic Activity, no. 2:385-421.

Gruber, Jonathan. 1994. "The Incidence of Mandated Maternity Benefits." American Economic Review 84, no. 3:622-41.

Gruber, Jonathan. 1997. "The Incidence of Payroll Taxation: Evidence from Chile." Journal of Labor Economics 15, no. 3, suppl.: S72-S101.

Gruber, Jonathan, and Alan Krueger. 1991. "The Incidence of Mandated Employer-Provided Insurance: Lessons from Workers' Compensation Insurance." In Tax Policy and the Economy, ed. David Bradford, 111-44. Cambridge, MA: MIT Press.

Hamermesh, Daniel. 1996. Labor Demand. Princeton: Princeton University Press.

Heckman, James, and Carmen Page's. 2004. "Introduction." In Law and Employment: Lessons from Latin America and the Caribbean, ed. James Heckman and Carmen Pages, 1-108. Chicago: University of Chicago Press/National Bureau of Economic Research.

Kaestner, Robert. 1996. "The Effect of Government-Mandated Benefits on Youth Employment." Industrial and Labor Relations Review 50, no. 1:122-42.

Kugler, Adriana. 1999. "The Impact of Firing Costs on Turnover and Unemployment: Evidence from the Colombian Labour Market Reform." International Tax and Public Finance 6, no. 3:389-410.

Kugler, Adriana. 2004. "The Effect of Job Security Provision Regulations on Labor Market Flexibility: Evidence from the Colombian Labor Market Reform." In Law and Employment: Lessons from Latin America and the Caribbean, ed. James Heckman and Carmen Page's, 183228. Chicago: University of Chicago Press/National Bureau of Economic Research.

Kugler, Adriana. 2005. "Wage-Shifting Effects of Severance Payments Savings Accounts in Colombia." Journal of Public Economics 89, nos. 2-3:487-500.

Kugler, Adriana. 2011. "Is there an Anti-labor Bias of Taxes? A Survey of the Evidence from Latin America and around the World," Research Department Publications No. 4746, InterAmerican Development Bank.

Kugler, Adriana, and Maurice Kugler. 2009. "Labor Market Effects of Payroll Taxes in Developing Countries: Evidence from Colombia," Economic Development and Cultural Change, 57(2): 335-358. 
Kugler, Adriana, Maurice Kugler, Juan E. Saavedra and Luis Omar Herrera. 2015. "The Longterm Direct and Spillovers Effects of Job Training: Experimental Evidence from Colombia," NBER Working Paper No. 21607.

Levy, Santiago. 2008. Good Intentions, Bad Outcomes: Social Policy, Informality, and Economic Growth in Mexico. Brookings Institution Press.

Maloney, William. 1999. "Does Informality Imply Segmentation in Urban Labor Markets? Evidence from Sectoral Transitions in Mexico." World Bank Economic Review 13, no. 2:275302.

Maloney, William. 2004. "Informality Revisited.” World Development 32, no. 7:1159-78.

Maloney, William, and Mariano Bosch. 2006. "Gross Worker Flows in the Presence of Informal Markets: The Mexican Experience, 1987-2002." Research Working Paper no. 3883, World Bank, Washington, DC.

Maloney, William, Edwin Goni, and Mariano Bosch. 2007. "The Determinants of Rising Informality in Brazil: Evidence from Gross Worker Flows.” Research Working Paper no. 4375, World Bank, Washington, DC.

Maloney, William, and Jairo Núnez. 2004. "Minimum Wages in Latin America." In Law and Employment: Lessons from Latin America and the Caribbean, ed. James Heckman and Carmen Pages, 109-30. Chicago: University of Chicago Press/National Bureau of Economic Research.

Nickell, Stephen, and Richard Layard. 1999. "Labor Market Institutions and Economic Performance." In Handbook of Labor Economics, vol. 3, ed. Orley Ashenfelter and David Card, 3029-84. New York: Elsevier.

OECD (Organization for Economic Cooperation and Development). 2015. Taxing Wages. Paris: OECD.

Vroman, Wayne. 1974. "Employer Payroll Taxes and Money Wage Behavior." Applied Economics 6, no. 3:189-2. 
Table 1: Descriptive Statistics for Household Survey, 2010-13

\begin{tabular}{lcccc}
\hline \hline & 2010 & 2011 & 2012 & 2013 \\
\hline Employer or Employee contributes to Social Security & 0.30 & 0.30 & 0.31 & 0.33 \\
Employer or Employee contributes to Pension Fund & 0.30 & 0.30 & 0.31 & 0.33 \\
Employer or Employee contributes to Health System & 0.37 & 0.38 & 0.38 & 0.39 \\
Workers' Compensation & 0.28 & 0.29 & 0.30 & 0.31 \\
Employer or Employee contributes to Pension/Health Fund & 0.37 & 0.38 & 0.39 & 0.40 \\
Self-Employed & 0.19 & 0.21 & 0.22 & 0.23 \\
Employee & 0.46 & 0.47 & 0.48 & 0.48 \\
Works for the same Company that Pays & 0.41 & 0.46 & 0.46 & 0.47 \\
Written Contract & 0.29 & 0.29 & 0.29 & 0.31 \\
Self-Employed with More than 2 People Hired & 0.05 & 0.06 & 0.06 & 0.07 \\
Income less than 10 MW & 0.997 & 0.997 & 0.996 & 0.995 \\
Firm with less than 10 Employers & 0.71 & 0.71 & 0.70 & 0.69 \\
Male & 0.60 & 0.59 & 0.59 & 0.59 \\
Cohabitants for Less than 2 years & 0.03 & 0.03 & 0.03 & 0.03 \\
Cohabitants for More than 2 years & 0.29 & 0.30 & 0.30 & 0.30 \\
Married & 0.26 & 0.25 & 0.24 & 0.24 \\
Other Marital Status & 0.42 & 0.42 & 0.43 & 0.42 \\
Less than High School & 0.05 & 0.05 & 0.04 & 0.04 \\
High-SchoolDegree & 0.59 & 0.57 & 0.58 & 0.56 \\
Trainning College Degree & 0.15 & 0.16 & 0.18 & 0.20 \\
University Degree or more & 0.21 & 0.21 & 0.20 & 0.20 \\
Illiterate & 0.05 & 0.05 & 0.05 & 0.05 \\
Number of Observations & 344,726 & 357,901 & 360,195 & 354,241 \\
\hline \hline Note: The tabe repts
\end{tabular}

Note: The table reports the percentaje of people with socio-economic and work characteristics from 2010 to 2013. 
Table 2: Descriptive Statistics for Social Security Records, 2008-2014

\begin{tabular}{|c|c|c|c|c|c|}
\hline & $\begin{array}{c}\text { Full Sample } \\
\text { (1) }\end{array}$ & $\begin{array}{c}\text { Firms }<3 \text { Employees } \\
(2)\end{array}$ & $\begin{array}{c}\text { Firms 4-10 Employees } \\
\text { (3) } \\
\end{array}$ & $\begin{array}{c}\text { Firms 11-50 Employees } \\
(4) \\
\end{array}$ & $\begin{array}{c}\text { Firms }>50 \text { Employees } \\
(5) \\
\end{array}$ \\
\hline \multirow[t]{2}{*}{ Firm Size } & 840.3 & 1.33 & 6.57 & 26.4 & $3,259.9$ \\
\hline & $(4,121.2)$ & $(0.59)$ & $(2.05)$ & $(11.42)$ & $(7,625.3)$ \\
\hline \multirow[t]{2}{*}{ Average wages / Minimum wages } & 0.52 & 0.33 & 0.70 & 0.89 & 1.67 \\
\hline & $(1.94)$ & $(1.24)$ & $(1.90)$ & $(2.11)$ & $(3.30)$ \\
\hline Probability of Transition from & 0.23 & 0.50 & 0.56 & 0.55 & 0.53 \\
\hline Non-employment to Employment & $(0.42)$ & $(0.54)$ & $(0.50)$ & $(0.50)$ & $(0.50)$ \\
\hline Number of Observations & $368,310,936$ & $32,240,555$ & $9,402,418$ & $20,038,184$ & $9,741,231$ \\
\hline
\end{tabular}

Note: This table shows the mean and standard deviation in parenthesis from a $25 \%$ randomized sample of the universe of Social Security records from January 2008 to

December 2014. Firm size is estimated as the number of people who report their payment for the same company. 


Mean

Share of Permanent Non-production Employees

52.2

$(109.0)$

Share of Permanent Production Employees

99.5

(171.4)

Regular Hours Permanent Non-production Employees

$19,587.1$

$(34,327.25)$

Extra Hours Permanent Non-production Employees

$(4,599.4)$

$160,799.1$

Salary of Permanent Non-production Employees

$(387,913.7)$

Salary of Permanent Production Employees

Number of Observations 120,770

Note: This table reports the mean and standard deviations (in parenthesis) of the share of production and non-production employees, and their regular and extraordinary hours as well as their salaries. 


$\begin{array}{ccccc}\text { Written } & \text { Health } & \text { Pension } & \begin{array}{c}\text { Health and } \\ \text { Pension } \\ \text { Contract }\end{array} & \begin{array}{c}\text { Workers' } \\ \text { Contribution Contribution }\end{array} \\ \begin{array}{c}\text { Contributionsation } \\ \text { Compens }\end{array} & \end{array}$

(1)

(2)

(3)

(4)

(5)

\begin{tabular}{|c|c|c|c|c|c|}
\hline \multirow[b]{2}{*}{ Less than 10 Minimum Wages X Reform } & \multicolumn{5}{|c|}{ Panel A. Full Sample } \\
\hline & $\begin{array}{c}0.085 * * \\
(0.031)\end{array}$ & $\begin{array}{c}0.134 * * * \\
(0.032)\end{array}$ & $\begin{array}{l}0.111^{*} \\
(0.054)\end{array}$ & $\begin{array}{c}0.124 * * * \\
(0.030)\end{array}$ & $\begin{array}{c}0.171 * * \\
(0.072)\end{array}$ \\
\hline Self-employed with More than 3 Workers X Reform & $\begin{array}{c}0.003 \\
(0.005)\end{array}$ & $\begin{array}{c}0.009 * * \\
(0.004)\end{array}$ & $\begin{array}{c}0.001 \\
(0.006)\end{array}$ & $\begin{array}{c}0.008 * * \\
(0.003)\end{array}$ & $\begin{array}{c}0.006 \\
(0.005)\end{array}$ \\
\hline \multirow[t]{2}{*}{ Number of Observations } & 377,669 & 377,669 & 377,669 & 377,669 & 377,669 \\
\hline & \multicolumn{5}{|c|}{ Panel B. Women } \\
\hline Less than 10 Minimum Wages X Reform & $\begin{array}{c}0.093 * * * \\
(0.017)\end{array}$ & $\begin{array}{c}0.155 * * * \\
(0.031)\end{array}$ & $\begin{array}{l}0.127 * \\
(0.063)\end{array}$ & $\begin{array}{c}0.149 * * * \\
(0.029)\end{array}$ & $\begin{array}{c}0.139 * * * \\
(0.036)\end{array}$ \\
\hline Self-employed with More than 3 Workers X Reform & $\begin{array}{l}-0.001 \\
(0.006)\end{array}$ & $\begin{array}{c}0.009 \\
(0.006)\end{array}$ & $\begin{array}{l}-0.004 \\
(0.011)\end{array}$ & $\begin{array}{c}0.005 \\
(0.005)\end{array}$ & $\begin{array}{c}0.002 \\
(0.011)\end{array}$ \\
\hline Number of Observations & Panel C. Men & 180,167 & $\begin{array}{l}180,167 \\
\text { Panel C }\end{array}$ & 180,167 & 180,167 \\
\hline Less than 10 Minimum Wages X Reform & $\begin{array}{c}0.078 * * \\
(0.037)\end{array}$ & $\begin{array}{c}0.092 * * * \\
(0.028)\end{array}$ & $\begin{array}{c}0.075 \\
(0.057)\end{array}$ & $\begin{array}{c}0.082 * * * \\
(0.026)\end{array}$ & $\begin{array}{c}0.142 \\
(0.092)\end{array}$ \\
\hline Self-employed with More than 3 Workers X Reform & $\begin{array}{c}0.007 \\
(0.007)\end{array}$ & $\begin{array}{l}0.010^{*} \\
(0.006)\end{array}$ & $\begin{array}{c}0.004 \\
(0.009)\end{array}$ & $\begin{array}{l}0.009^{*} \\
(0.005)\end{array}$ & $\begin{array}{c}0.010 \\
(0.006)\end{array}$ \\
\hline Number of Observations & 197,482 & 197,482 & 197,482 & 197,482 & 197,482 \\
\hline
\end{tabular}

Note: The table reports coeficients and clustered standard errors by department (in parenthesis) of linear probability models of different measures of formality on the interaction terms of the post-reform dummy with indicators of whether the worker earns less than $10 \mathrm{MW}$ or the workers is selfemployed and hires more than 2 employees. The formality measures include: a Written Contract dummy; an indicator of whether the employer or employee pay Health and Pension Contributions; an indicator of whether the employee is covered by Workers' Compensation. To estimate the share of workers paid less than $10 \mathrm{MW}$, wages (deflated to their real value at 2013 prices) were divided by the Colombian Minimun Wage of 589,500 pesos in 2013 pesos. All regressions control for age, age squared, years of education, education squared, a male dummy, dummies for marital status, the number of MW the indiviudal earns, the worker's type, firm size, the interaction between firm size and worker type and fixed effects for industry and year. *** $\mathrm{p}<0.01, \mathrm{p}<0.05,{ }^{*} \mathrm{p}<0.1$. 
Table 5: Effects of the Tax Reform on Formality by Firm Size, Household Surveys

\begin{tabular}{|c|c|c|c|c|c|}
\hline & $\begin{array}{c}\text { Written } \\
\text { Contract } \\
\text { (1) }\end{array}$ & $\begin{array}{c}\text { Health } \\
\text { Contribution } \\
\text { (2) }\end{array}$ & $\begin{array}{c}\text { Pension } \\
\text { Contribution } \\
\text { (3) }\end{array}$ & $\begin{array}{l}\text { Health and } \\
\text { Pension } \\
\text { Contribution } \\
\text { (4) }\end{array}$ & $\begin{array}{c}\text { Workers' } \\
\text { Compensation } \\
\text { (5) }\end{array}$ \\
\hline & \multicolumn{5}{|c|}{ Panel A. Full Sample } \\
\hline Less than 10 Minimum Wages X Reform & $\begin{array}{r}0.085^{* *} \\
(0.031)\end{array}$ & $\begin{array}{c}0.134 * * * \\
(0.032)\end{array}$ & $\begin{array}{l}0.111^{*} \\
(0.054)\end{array}$ & $\begin{array}{c}0.124 * * * \\
(0.030)\end{array}$ & $\begin{array}{r}0.171 * * \\
(0.072)\end{array}$ \\
\hline Self-employed with More than 3 Workers & $\begin{array}{l}0.003 \\
(0.005)\end{array}$ & $\begin{array}{r}0.009^{* *} \\
(0.004)\end{array}$ & $\begin{array}{l}0.001 \\
(0.006)\end{array}$ & $\begin{array}{r}0.008 * * \\
(0.003)\end{array}$ & $\begin{array}{l}0.006 \\
(0.005)\end{array}$ \\
\hline Number of Observations & \multicolumn{5}{|c|}{ Panel B. Less than 10 Employees } \\
\hline Less than 10 Minimum Wages X Reform & $\begin{array}{c}2.343 * * * \\
(0.567)\end{array}$ & $\begin{array}{c}2.679 * * * \\
(0.770)\end{array}$ & $\begin{array}{c}2.323 * * * \\
(0.674)\end{array}$ & $\begin{array}{c}2.713 * * * \\
(0.763)\end{array}$ & $\begin{array}{c}2.253 * * * \\
(0.669)\end{array}$ \\
\hline Self-employed with More than 3 Workers & $\begin{array}{c}0.057 * * * \\
(0.012)\end{array}$ & $\begin{array}{c}0.065^{* * *} \\
(0.014)\end{array}$ & $\begin{array}{c}0.059 * * * \\
(0.012)\end{array}$ & $\begin{array}{c}0.065^{* * *} \\
(0.014)\end{array}$ & $\begin{array}{c}0.056^{* * *} \\
(0.011)\end{array}$ \\
\hline Number of Observations & 101,062 & 101,062 & 101,062 & 101,062 & 101,062 \\
\hline & \multicolumn{5}{|c|}{ Panel C. Firms with more than 11 and less than 50 employees } \\
\hline Less than 10 Minimum Wages X Reform & $\begin{array}{c}0.216 * * * \\
(0.071)\end{array}$ & $\begin{array}{c}0.297 * * * \\
(0.080)\end{array}$ & $\begin{array}{c}0.280 * * * \\
(0.087)\end{array}$ & $\begin{array}{c}0.299 * * * \\
(0.079)\end{array}$ & $\begin{array}{c}0.252 * * * \\
(0.081)\end{array}$ \\
\hline Self-employed with More than 3 Workers & $\begin{array}{c}0.004 \\
(0.011)\end{array}$ & $\begin{array}{c}0.004 \\
(0.011)\end{array}$ & $\begin{array}{c}0.015 \\
(0.009)\end{array}$ & $\begin{array}{c}0.003 \\
(0.010)\end{array}$ & $\begin{array}{c}0.015 \\
(0.009)\end{array}$ \\
\hline Number of Observations & 61,666 & 61,666 & 61,666 & 61,666 & 61,666 \\
\hline & \multicolumn{5}{|c|}{ Panel D. More than 50 Employees } \\
\hline Less than 10 Minimum Wages X Reform & $\begin{array}{r}0.025^{* *} \\
(0.009)\end{array}$ & $\begin{array}{c}0.040^{* * *} \\
(0.014)\end{array}$ & $\begin{array}{c}0.055^{* * *} \\
(0.016)\end{array}$ & $\begin{array}{c}0.038^{* * * *} \\
(0.011)\end{array}$ & $\begin{array}{r}0.052 * * \\
(0.020)\end{array}$ \\
\hline Self-employed with More than 3 Workers & $\begin{array}{c}0.000 \\
(0.002)\end{array}$ & $\begin{array}{c}0.003 \\
(0.002)\end{array}$ & $\begin{array}{l}0.005^{*} \\
(0.003)\end{array}$ & $\begin{array}{c}0.002 \\
(0.002)\end{array}$ & $\begin{array}{l}0.005 \\
(0.004)\end{array}$ \\
\hline Number of Observations & 191,158 & 191,158 & 191,158 & 191,158 & 191,158 \\
\hline
\end{tabular}

Note: The table reports coeficients and clustered standard errors by department (in parenthesis) of linear probability models of formality on interactions of Less than $10 \mathrm{MW}$ and Self-Employed who hire more than 3 Workers by firm size. The following measures of formality are used: a Written Contract Dummy; an indicator of whether the employer or employee contributes to Health and Pension funds; an indicator of wether the worker is covered by Workers' Compensation. All regressions include controls for: age, age squared, year of education, education squared, a male dummy, marital status dummy, the share of wages out of the MW, firm size, type of worker indicators and interaction of firm size with type of worker and fixed effects by industry. $* * * \mathrm{p}<0.01, * * \mathrm{p}<0.05,{ }^{*} \mathrm{p}<0.1$. 
Table 6: Placebo Effects of Less than 20 MW on Formality, Household Surveys

\begin{tabular}{|c|c|c|c|c|c|}
\hline & $\begin{array}{c}\text { Written } \\
\text { contract } \\
(1) \\
\end{array}$ & $\begin{array}{c}\text { Health } \\
\text { Contribution } \\
(2) \\
\end{array}$ & $\begin{array}{c}\text { Pension } \\
\text { Contribution } \\
(3) \\
\end{array}$ & $\begin{array}{c}\text { Health and } \\
\text { Pension } \\
\text { Contribution } \\
(4) \\
\end{array}$ & $\begin{array}{c}\text { Workers } \\
\text { Compensation } \\
(5) \\
\end{array}$ \\
\hline & \multicolumn{5}{|c|}{ Panel A. Full Sample } \\
\hline \multirow[t]{2}{*}{ Less than 20 Minimum Wages X Reform } & -0.005 & -0.001 & -0.025 & -0.004 & -0.004 \\
\hline & $(0.012)$ & $(0.013)$ & $(0.021)$ & $(0.010)$ & $(0.021)$ \\
\hline \multirow[t]{2}{*}{ Self-employed with More than 3 Workers X Reform } & 0.010 & 0.003 & 0.006 & 0.000 & -0.008 \\
\hline & $(0.016)$ & $(0.017)$ & $(0.029)$ & $(0.014)$ & $(0.028)$ \\
\hline \multirow[t]{2}{*}{ Number of Observations } & 153,533 & 153,533 & 153,533 & 153,533 & 153,533 \\
\hline & \multicolumn{5}{|c|}{ Panel B. Women } \\
\hline \multirow[t]{2}{*}{ Less than 20 Minimum Wages X Reform } & -0.001 & -0.010 & -0.054 & -0.005 & 0.006 \\
\hline & $(0.016)$ & $(0.022)$ & $(0.036)$ & $(0.014)$ & $(0.041)$ \\
\hline \multirow[t]{2}{*}{ Self-employed with More than 3 Workers X Reform } & 0.020 & 0.034 & -0.016 & 0.014 & $-0.104 *$ \\
\hline & $(0.022)$ & $(0.030)$ & $(0.051)$ & $(0.019)$ & $(0.057)$ \\
\hline \multirow[t]{2}{*}{ Number of Observations } & 47,134 & 47,134 & 47,134 & 47,134 & 47,134 \\
\hline & \multicolumn{5}{|c|}{ Panel C. Men } \\
\hline \multirow[t]{2}{*}{ Less than 20 Minimum Wages X Reform } & 0.006 & 0.010 & -0.005 & 0.004 & 0.001 \\
\hline & $(0.015)$ & $(0.016)$ & $(0.026)$ & $(0.014)$ & $(0.025)$ \\
\hline \multirow[t]{2}{*}{ Self-employed with More than 3 Workers X Reform } & 0.009 & -0.016 & 0.001 & -0.014 & 0.011 \\
\hline & $(0.021)$ & $(0.022)$ & $(0.036)$ & $(0.019)$ & $(0.034)$ \\
\hline Number of Observations & 106,398 & 106,398 & 106,398 & 106,398 & 106,398 \\
\hline
\end{tabular}


Table 7: Effects of Payroll Tax Reform and First Employment Reform on Formality, Household Surveys

\begin{tabular}{|c|c|c|c|c|c|}
\hline & $\begin{array}{c}\text { Written } \\
\text { Contract } \\
(1) \\
\end{array}$ & $\begin{array}{c}\text { Health } \\
\text { Contribution } \\
(2) \\
\end{array}$ & $\begin{array}{c}\text { Pension } \\
\text { Contribution } \\
(3) \\
\end{array}$ & $\begin{array}{c}\text { Health and } \\
\text { Pension } \\
\text { Contribution } \\
\text { (4) }\end{array}$ & $\begin{array}{c}\text { Workers' } \\
\text { Compensation } \\
(5) \\
\end{array}$ \\
\hline Less than 10 Minimum Wages X 2010 & $\begin{array}{c}0.224 * * * \\
(0.036)\end{array}$ & $\begin{array}{c}0.240 * * * \\
(0.044)\end{array}$ & $\begin{array}{c}0.238^{* * *} \\
(0.040)\end{array}$ & $\begin{array}{c}0.240 * * * \\
(0.041)\end{array}$ & $\begin{array}{c}0.248 * * * \\
(0.049)\end{array}$ \\
\hline Self-employed with More than 3 Workers X Reform & $\begin{array}{c}-0.034 * * * \\
(0.004)\end{array}$ & $\begin{array}{c}-0.025^{* * *} \\
(0.004)\end{array}$ & $\begin{array}{c}-0.026^{* * *} \\
(0.004)\end{array}$ & $\begin{array}{c}-0.026 * * * \\
(0.004)\end{array}$ & $\begin{array}{c}-0.027 * * * \\
(0.005)\end{array}$ \\
\hline Less than 29 Years Old X 2010 & $\begin{array}{l}-0.006 \\
(0.004)\end{array}$ & $\begin{array}{l}-0.001 \\
(0.004)\end{array}$ & $\begin{array}{c}0.006 \\
(0.005)\end{array}$ & $\begin{array}{c}0.001 \\
(0.004)\end{array}$ & $\begin{array}{c}0.003 \\
(0.005)\end{array}$ \\
\hline Women older than 40 Years Old X 2010 & $\begin{array}{c}-0.021 * * * \\
(0.004)\end{array}$ & $\begin{array}{c}-0.013 * * * \\
(0.004)\end{array}$ & $\begin{array}{c}-0.006 \\
(0.004)\end{array}$ & $\begin{array}{c}-0.013 * * * \\
(0.004)\end{array}$ & $\begin{array}{c}-0.012 * * * \\
(0.004)\end{array}$ \\
\hline Less than 1.5 Mminimum Wages X 2010 & $\begin{array}{c}-0.000 * * * \\
(0.000)\end{array}$ & $\begin{array}{c}-0.000 * * * \\
(0.000)\end{array}$ & $\begin{array}{c}-0.000 * * * \\
(0.000)\end{array}$ & $\begin{array}{c}-0.000 * * * \\
(0.000)\end{array}$ & $\begin{array}{c}-0.000 * * * \\
(0.000)\end{array}$ \\
\hline Times Real Minimum Wage & $\begin{array}{c}0.009 * * * \\
(0.003)\end{array}$ & $\begin{array}{c}0.009 * * \\
(0.003)\end{array}$ & $\begin{array}{c}0.009 * * * \\
(0.003)\end{array}$ & $\begin{array}{c}0.008 * * * \\
(0.003)\end{array}$ & $\begin{array}{c}0.011 * * * \\
(0.004)\end{array}$ \\
\hline Number of Observations & 377,669 & 377,669 & 377,669 & 377,669 & 377,669 \\
\hline
\end{tabular}

Note: The table reports coeficients and clustered standard errors by department (in parenthesis) of linear probability models of different measures of formality on the interaction terms of the post-reform dummy with indicators of whether the worker earns less than $10 \mathrm{MW}$ or the workers is self-employed and hires more than 2 employees. The formality measures include: a Written Contract dummy; an indicator of whether the employer or employee pay Health and Pension Contributions; an

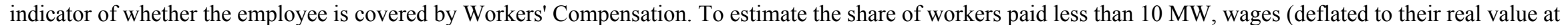

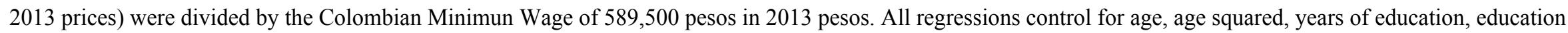
squared, a male dummy, dummies for marital status, the number of MW the indiviudal earns, the worker's type, firm size, the interaction between firm size and worker type and fixed effects for industry and year. ${ }^{* * *} \mathrm{p}<0.01, \mathrm{p}<0.05, * \mathrm{p}<0.1$. 
Table 8: Effects of Payroll Tax Reform on Transitions to Registered Empoyment by Firm Size, Social Security Records

\begin{tabular}{|c|c|c|c|c|c|c|c|c|c|c|}
\hline & \multicolumn{2}{|c|}{ Full Sample } & \multicolumn{2}{|c|}{ Up to 3 workers } & \multicolumn{2}{|c|}{ More than 3 to 10 workers } & \multicolumn{2}{|c|}{ More than 10 to 50 workers } & \multicolumn{2}{|c|}{ More than 50 workers } \\
\hline & $(1)$ & $(2)$ & (3) & $(4)$ & $(5)$ & $(6)$ & $(7)$ & $(8)$ & (9) & $(10)$ \\
\hline Less than $10 \mathrm{MW}$ X Reform & $\begin{array}{c}0.035 * * * \\
(0.001)\end{array}$ & & $\begin{array}{c}0.394 * * * \\
(0.006)\end{array}$ & & $\begin{array}{c}0.297 * * * \\
(0.007)\end{array}$ & & $\begin{array}{c}-0.102 * * * \\
(0.003)\end{array}$ & & $\begin{array}{c}-0.058 * * * \\
(0.001)\end{array}$ & \\
\hline Self-empl. w/ More than 3 Workers X Reform & $\begin{array}{c}0.163 * * * \\
(0.001)\end{array}$ & $\begin{array}{c}0.168 * * * \\
(0.001)\end{array}$ & & & $\begin{array}{c}0.142 * * * \\
(0.001)\end{array}$ & $\begin{array}{c}0.117 * * * \\
(0.001)\end{array}$ & $\begin{array}{c}0.059 * * * \\
(0.002)\end{array}$ & $\begin{array}{c}0.060 * * * \\
(0.002)\end{array}$ & $\begin{array}{c}0.075 * * * \\
(0.002)\end{array}$ & $\begin{array}{l}0.074 * * * \\
(0.002)\end{array}$ \\
\hline 0-2 Minimum Wages X Reform & & $\begin{array}{c}0.051 * * * \\
(0.001)\end{array}$ & & $\begin{array}{c}0.457 * * * \\
(0.008)\end{array}$ & & $\begin{array}{c}0.228 * * * \\
(0.007)\end{array}$ & & $\begin{array}{c}-0.106 * * * \\
(0.003)\end{array}$ & & $\begin{array}{l}-0.053 * * * \\
(0.001)\end{array}$ \\
\hline 3-5 Minimum Wages X Reform & & $\begin{array}{c}0.020 * * * \\
(0.001)\end{array}$ & & $\begin{array}{c}0.393 * * * \\
(0.007)\end{array}$ & & $\begin{array}{c}0.363 * * * \\
(0.006)\end{array}$ & & $\begin{array}{c}-0.102 * * * \\
(0.003)\end{array}$ & & $\begin{array}{l}-0.073 * * * \\
(0.001)\end{array}$ \\
\hline 6-10 Minimum Wages X Reform & & $\begin{array}{c}0.010 * * * \\
(0.001)\end{array}$ & & $\begin{array}{c}0.267 * * * \\
(0.005)\end{array}$ & & $\begin{array}{c}0.255^{* * *} * \\
(0.006)\end{array}$ & & $\begin{array}{c}-0.091 * * * \\
(0.003)\end{array}$ & & $\begin{array}{l}-0.052 * * * \\
(0.001)\end{array}$ \\
\hline Reported Wages / Minimun Wages & $\begin{array}{c}0.001 * * * \\
(0.000)\end{array}$ & $\begin{array}{c}0.001 * * * \\
(0.000)\end{array}$ & $\begin{array}{c}0.023 * * * \\
(0.000)\end{array}$ & $\begin{array}{c}0.026^{* * *} \\
(0.000)\end{array}$ & $\begin{array}{c}0.017 * * * \\
(0.000)\end{array}$ & $\begin{array}{c}0.014 * * * \\
(0.000)\end{array}$ & $\begin{array}{c}-0.005 * * * \\
(0.000)\end{array}$ & $\begin{array}{c}-0.005^{* * * *} \\
(0.000)\end{array}$ & $\begin{array}{c}-0.004 * * * \\
(0.000)\end{array}$ & $\begin{array}{l}-0.004 * * * \\
(0.000)\end{array}$ \\
\hline Reform & $\begin{array}{c}-0.038 * * * \\
(0.001)\end{array}$ & $\begin{array}{c}-0.051 * * * \\
(0.001)\end{array}$ & $\begin{array}{c}-0.367 * * * \\
(0.006)\end{array}$ & $\begin{array}{c}-0.423 * * * \\
(0.007)\end{array}$ & $\begin{array}{c}-0.341 * * * \\
(0.006)\end{array}$ & $\begin{array}{c}-0.299 * * * \\
(0.006)\end{array}$ & $\begin{array}{c}0.098 * * * \\
(0.003)\end{array}$ & $\begin{array}{c}0.102 * * * \\
(0.003)\end{array}$ & $\begin{array}{c}0.061 * * * \\
(0.001)\end{array}$ & $\begin{array}{l}0.059 * * * \\
(0.001)\end{array}$ \\
\hline Number of Observations & 7,200 & 0,257 & 16,12 & 5,810 & $4,717,052$ & & $10,005,116$ & & $47,352,279$ & \\
\hline
\end{tabular}

Note: The table reports coeficients and clustered standard errors by indiviudal (in parenthesis) of linear probability models of the transition to registered employment. All regressions control for the ratio of reported

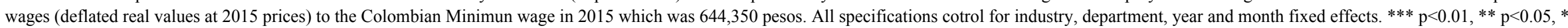
$\mathrm{p}<0.1$. 
Table 9: Effects of the Payroll Tax Reform on Manufacturing Employment, Monthly Manufacturing Sample

\begin{tabular}{|c|c|c|c|c|c|c|}
\hline & $\begin{array}{c}\text { Number of } \\
\text { Permanent Non- } \\
\text { Production } \\
\text { Employees } \\
\text { (1) }\end{array}$ & $\begin{array}{l}\text { Number of } \\
\text { Permanent } \\
\text { Production } \\
\text { Employees } \\
\text { (2) }\end{array}$ & $\begin{array}{l}\text { \% Permanent Non- } \\
\text { production } \\
\text { Employees } \\
\text { (3) }\end{array}$ & $\begin{array}{l}\text { \% Permanent } \\
\text { Production } \\
\text { Employees }\end{array}$ & $\begin{array}{l}\text { Regulat Hours for } \\
\text { All Permanent } \\
\text { Employees } \\
\text { (5) }\end{array}$ & $\begin{array}{c}\text { Extraordinary } \\
\text { Hours for All } \\
\text { Permanent } \\
\text { Employees } \\
(6)\end{array}$ \\
\hline & \multicolumn{6}{|c|}{ Panel A. Full Sample } \\
\hline Average Wages Less than 10 MW X Reform & $\begin{array}{c}46.164 * * * \\
(12.299)\end{array}$ & $\begin{array}{c}253.904 * * * \\
(36.251)\end{array}$ & $\begin{array}{l}0.104 * * \\
(0.041)\end{array}$ & $\begin{array}{c}-0.073 \\
(0.113)\end{array}$ & $\begin{array}{l}-278.551^{*} \\
(146.293)\end{array}$ & $\begin{array}{l}-37.942 \\
(27.730)\end{array}$ \\
\hline Average Wages / Minimun Wages & $\begin{array}{c}4.696 * * * \\
(0.913)\end{array}$ & $\begin{array}{c}17.510 * * * \\
(4.765)\end{array}$ & $\begin{array}{c}0.004 \\
(0.004)\end{array}$ & $\begin{array}{l}-0.012 * \\
(0.007)\end{array}$ & $\begin{array}{c}1.020 \\
(0.806)\end{array}$ & $\begin{array}{c}0.097 \\
(0.178)\end{array}$ \\
\hline Number of Observations & \multicolumn{5}{|c|}{ Panel B. Less than 4 employees } & 98,953 \\
\hline Average Wages Less than 10 MW X Reform & $\begin{array}{c}2.363 * * \\
(0.897)\end{array}$ & $\begin{array}{c}5.961 * * * \\
(1.177)\end{array}$ & $\begin{array}{c}0.858 * * * \\
(0.199)\end{array}$ & $\begin{array}{c}0.294 \\
(0.202)\end{array}$ & $\begin{array}{c}-2,545.175^{* * *} \\
(95.998)\end{array}$ & $\begin{array}{l}-29.745^{* *} \\
(12.110)\end{array}$ \\
\hline Average Wages / Minimun Wages & $\begin{array}{c}0.157 * * * \\
(0.053)\end{array}$ & $\begin{array}{c}0.633 * * * \\
(0.107)\end{array}$ & $\begin{array}{c}0.110 * * * \\
(0.028)\end{array}$ & $\begin{array}{l}0.041 * \\
(0.023)\end{array}$ & $\begin{array}{c}33.558 * * * \\
(8.607)\end{array}$ & $\begin{array}{c}3.138 * * * \\
(1.079)\end{array}$ \\
\hline \multirow[t]{2}{*}{ Number of Observations } & 5,169 & 5,169 & 5,169 & 5,169 & 5,169 & 5,169 \\
\hline & \multicolumn{6}{|c|}{ Panel C. More than 4 and less than 10 employees } \\
\hline Average Wages Less than 10 MW X Reform & $\begin{array}{c}3.077 * * * \\
(0.932)\end{array}$ & $\begin{array}{c}9.482 * * * \\
(2.152)\end{array}$ & $\begin{array}{c}0.555^{* * *} \\
(0.198)\end{array}$ & $\begin{array}{l}0.439 * * \\
(0.188)\end{array}$ & $\begin{array}{c}-1,830.071 * \\
(942.582)\end{array}$ & $\begin{array}{l}-31.833 \\
(27.470)\end{array}$ \\
\hline Average Wages / Minimun Wages & $\begin{array}{c}0.283 * * * \\
(0.078)\end{array}$ & $\begin{array}{c}0.817 * * * \\
(0.187)\end{array}$ & $\begin{array}{c}0.048 * * * \\
(0.015)\end{array}$ & $\begin{array}{l}0.022 * \\
(0.012)\end{array}$ & $\begin{array}{c}10.135 * * * \\
(3.687)\end{array}$ & $\begin{array}{l}0.830 * * \\
(0.344)\end{array}$ \\
\hline \multirow[t]{2}{*}{ Number of Observations } & 7,844 & 7,844 & 7,844 & 7,844 & 7,844 & 7,844 \\
\hline & \multicolumn{6}{|c|}{ Panel D. More than 10 and less than 50 employees } \\
\hline Average Wages Less than $10 \mathrm{MW} X$ Reform & $\begin{array}{c}4.839 * * * \\
(1.708)\end{array}$ & $\begin{array}{c}17.002 * * * \\
(4.961)\end{array}$ & $\begin{array}{c}0.020 \\
(0.103)\end{array}$ & $\begin{array}{c}0.171 \\
(0.172)\end{array}$ & $\begin{array}{c}-437.734 \\
(308.641)\end{array}$ & $\begin{array}{l}-75.621 \\
(69.687)\end{array}$ \\
\hline Average Wages / Minimun Wages & $\begin{array}{c}0.363 * * * \\
(0.102)\end{array}$ & $\begin{array}{c}0.714 \\
(0.452)\end{array}$ & $\begin{array}{l}-0.000 \\
(0.006)\end{array}$ & $\begin{array}{l}0.025^{*} \\
(0.014)\end{array}$ & $\begin{array}{l}-0.255 \\
(2.564)\end{array}$ & $\begin{array}{c}0.221 \\
(0.488)\end{array}$ \\
\hline Number of Observations & 21,205 & 21,205 & 21,205 & 21,205 & 21,205 & 21,205 \\
\hline Average Wages Less than 10 MW X Reform & $\begin{array}{c}35.356^{* * *} \\
(11.132)\end{array}$ & $\begin{array}{c}168.972 * * * \\
(54.994)\end{array}$ & $\begin{array}{c}\text { Panel E. More tha } \\
0.030 \\
(0.029)\end{array}$ & $\begin{array}{c}50 \text { employees } \\
0.006 \\
(0.136)\end{array}$ & $\begin{array}{l}-88.831 \\
(66.200)\end{array}$ & $\begin{array}{l}-16.047 \\
(11.642)\end{array}$ \\
\hline Average Wages / Minimun Wages & $\begin{array}{c}3.180 * * * \\
(1.129)\end{array}$ & $\begin{array}{c}10.364 * * \\
(4.831)\end{array}$ & $\begin{array}{l}-0.007 * \\
(0.004)\end{array}$ & $\begin{array}{l}-0.013 * \\
(0.007)\end{array}$ & $\begin{array}{l}-0.772 \\
(1.406)\end{array}$ & $\begin{array}{l}-0.230 \\
(0.270)\end{array}$ \\
\hline Number of Observations & 64,777 & 64,777 & 64,777 & 64,777 & 64,777 & 64,777 \\
\hline
\end{tabular}

Note: The table reports the coeficients and robust standard error (in parenthesis) by firm size. The regressions include controls for average (deflated in real 2015 values) divided by the minimung

wage of 2015 (644.350 Colombian pesos). All specifications control for industry, department, year and month fixed effects. ${ }^{* * *} \mathrm{p}<0.01,{ }^{* *} \mathrm{p}<0.05,{ }^{*} \mathrm{p}<0.1$. 
Table 10: Placebo Effects of Less than 20 MW on Manufacturing Employment, Monthly Manufacturing Sample

\begin{tabular}{|c|c|c|c|c|c|c|}
\hline & $\begin{array}{c}\text { Number of } \\
\text { Permanent } \\
\text { Non- } \\
\text { Production } \\
\text { Employees } \\
\text { (1) }\end{array}$ & $\begin{array}{l}\text { Number of } \\
\text { Permanent } \\
\text { Production } \\
\text { Employees } \\
\text { (2) }\end{array}$ & $\begin{array}{c}\% \\
\text { Permanent } \\
\text { Non- } \\
\text { production } \\
\text { Employees } \\
(3)\end{array}$ & $\begin{array}{l}\text { \% Permanent } \\
\text { Production } \\
\text { Employees }\end{array}$ & $\begin{array}{l}\text { Regulat Hours } \\
\text { for All } \\
\text { Permanent } \\
\text { Employees } \\
\text { (5) }\end{array}$ & $\begin{array}{c}\text { Extraordinary } \\
\text { Hours for All } \\
\text { Permanent } \\
\text { Employees } \\
\text { (6) }\end{array}$ \\
\hline Average Wages Less than 20 MW X Reform & $\begin{array}{l}10.877 \\
(9.613)\end{array}$ & $\begin{array}{c}7.833 \\
(4.998)\end{array}$ & $\begin{array}{l}-0.065 \\
(0.071)\end{array}$ & $\begin{array}{c}0.171 * * \\
(0.064)\end{array}$ & $\begin{array}{c}-174.418 * * * \\
(57.207)\end{array}$ & $\begin{array}{c}-15.042 * * \\
(5.406)\end{array}$ \\
\hline Average Wages / Minimun Wages & $\begin{array}{c}-3.560 * * * \\
(1.216)\end{array}$ & $\begin{array}{l}-0.043 \\
(0.188)\end{array}$ & $\begin{array}{c}-0.007 * * \\
(0.003)\end{array}$ & $\begin{array}{c}-0.006^{* * *} \\
(0.002)\end{array}$ & $\begin{array}{l}-2.783 \\
(1.609)\end{array}$ & $\begin{array}{l}-0.239 \\
(0.141)\end{array}$ \\
\hline Number of Observations & 4,358 & 4,358 & 4,358 & 4,358 & 4,358 & 4,358 \\
\hline
\end{tabular}


Figure 1. Share of firms by department in the MMS

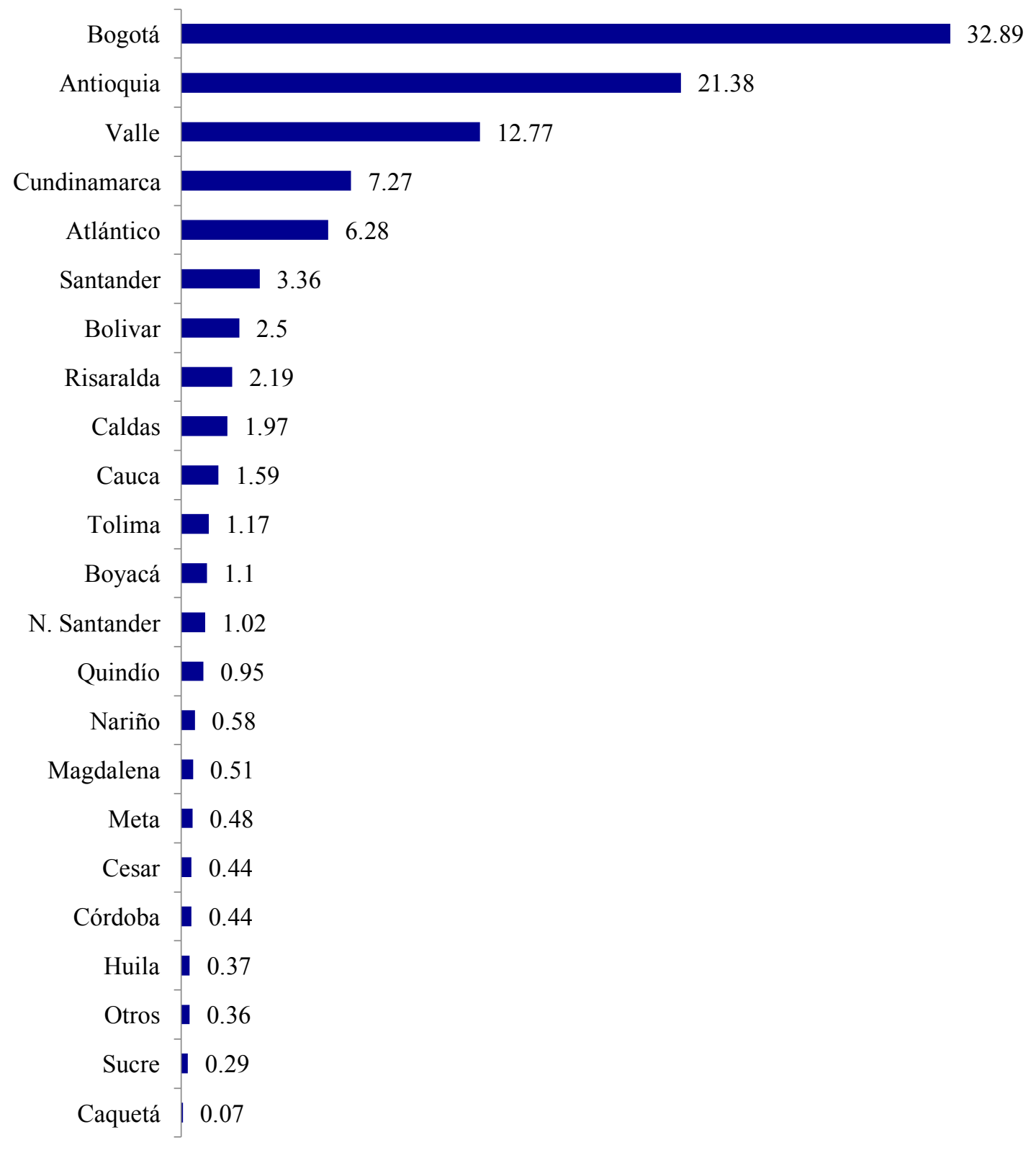

Note: This figure reports share of establishments in each department from MMS data for the years 2008-2014. 